\title{
高温岩体発電 システム
}

\section{一地熱資源の新しい利用方法一}

-1988. 2. 16 受理一

公害資源研究所 厨川道 雄

1. はじめに

地球はよく卵に例えられる。われわれの住んでいる 地球の表面は地殼と呼ばれ, 卵の“から”に相当する。 この地殼は, 地球内部のマグマなどの熱によって暖め られ，深くなる程，温度が高くなる。とくに，火山な どマグマが地表近くまで貫入している所では，他の場 所に比べてかなり温度が高くなっている。このような 所海雨水など地表水が侵入して，暖められて岩盤のな かに貯えられると，地熱貯留層が形成される。この地 熱眝留層まで穴(坑井と呼ばれる)を掘り, 高温かつ高 圧の熱水と蒸気を取り出して発電するいわゆる地熱発 電は, アメリカをはじめ世界全国で行われている。

日本は，世界有数の火山国で地熱資源はきわめて恵 まれている国の一つである。全世界の約 1 割に相当す る地熱エネルギーが日本列島周辺に存在するとも言わ れている。この豊富な地熱資源を活かして，現在わが 国では大分県九重町の八丁原発電所をはじ め, 表 1 に示すように 9 力所の地熱発電所 が稼働しており, 合計設備能力は 21.5 万 $\mathrm{kW}$ である。さらに, 数力所で地熱開発が 進められており, 今後発電能力も大きく増 大することが期待されている。これらの地 熱発電所では, おおよそ $2,000 \mathrm{~m}$ までの坑 井を掘削し, 地下の天然貯留層から蒸気や 熱水を自噴させて発電に利用している。

しかし, 地下の岩盤の温度が十分高くと も, 暖められた水が逸散したり, 地上から の水の供給がなかったりなどで, 蒸気や熱 水の貯留層が形成されていない所も多い。 このよらに，十分な熱エネルギーを持って
いるにもかかわらず，貯留層を有しない岩盤を高温岩 体 (hot dry rock) と呼んでいる。高温岩体の資源量は, 正確には把握されていないが，米国における推定資源 量は，現在消費している年間エネルギー量の 30 倍相当 といわれている。わが国は，火山国であることから， 米国上りも条件がよく, 莫大な高温岩体資源量を保有 していることは言うまでもない。高温岩体発電技術が 開発されれば, 利用できる地熱資源量は飛躍的に増加 することが期待できる。

\section{2. 高温岩体開発の概念}

高温岩体の熱エネルギーを開発する方法は, 米国二 ューメキシコ州ロスアラモス国立研究所のモートン. スミス氏らによって考案された。このアイデアは図 1 に示すように, 深さ $2,000 \mathrm{~m} \sim 5,000 \mathrm{~m}$ で温度 $300^{\circ} \mathrm{C}$ 程 度の低透水性の岩盤に坑井を掘り, 水圧破砕すなわち 高圧の水を注入することによって岩盤に割れ目を造る。

\section{表1 日本国内の地熱発電所}

\begin{tabular}{|c|c|c|c|c|}
\hline 発 & 電 所 & 名 & 所 在 地 & 出 力 $[\mathrm{kW}]$ \\
\hline 松 & & 川 & 岩手県松尾村 & 22,000 \\
\hline 大 & & 岳 & 大分県九重町 & 12,500 \\
\hline 大 & & 沼 & 秋田県鹿角市 & 10,000 \\
\hline 鬼 & & 首 & 宮城県鳴子町 & 12,500 \\
\hline 八 & 丁 & 原 & 大分県九重町 & 55,000 \\
\hline 葛 & 根 & 田 & 岩手県零石町 & 50,000 \\
\hline & 乃 & 井 & \multirow{2}{*}{$\begin{array}{l}\text { 大分県別府市 } \\
\text { 北海道森町 }\end{array}$} & 3,000 \\
\hline \multirow{2}{*}{\multicolumn{3}{|c|}{$\begin{array}{l}\text { 秝 } \\
\text { 霧島国際ホテル }\end{array}$}} & & 50,000 \\
\hline & & & 鹿児島県牧園町 & 100 \\
\hline \multicolumn{2}{|l|}{ 合 } & & 9 ケ 所 & 215,100 \\
\hline
\end{tabular}

資源第 4 部 茨城県つくば市小野川 $16-3$ 


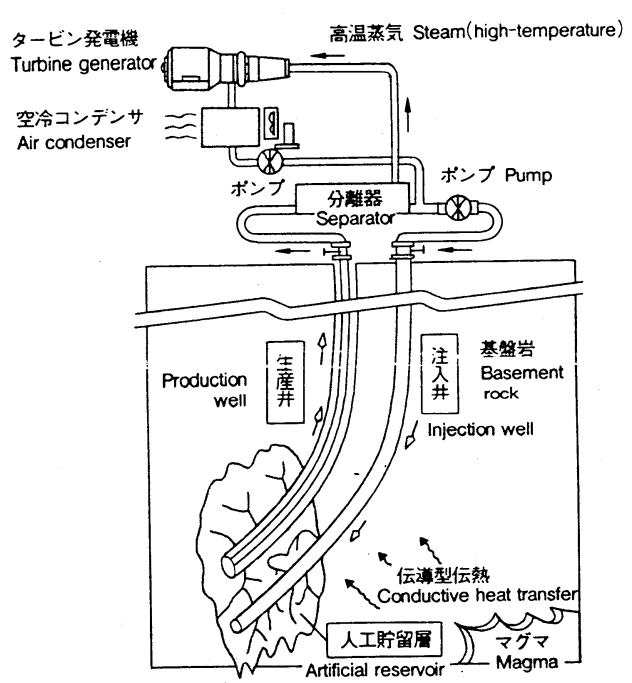

図 1 高温岩体発電システムの概念

次に,この割れ目を貫くようにもら 1 本の坑井を掘っ て，2 本の坑井と割れ目からなる循環系を完成させる。 一方の坑井 (注入井) から冷たい水を入れて, 人工貯留 層となる割れ目で暖めて, 蒸気や熱水としてもら一方 の坑井 (生産井)から回収する。この蒸気や熱水を用い て発電し, 使用後の熱水を再び注入井に送り込む。言 い換えれば，高温の岩盤に造られた人工貯留層を一種 の大規模なボイラーとして, 利用しようとする考えで ある。

この方式の利点として, 次のことが挙げられる。

1）同じ水を循環して利用するため, 外部に漏れない ので環境に与える影響が少ない。

2）地下に天然に存在する貯留層を利用しないので, この方式によって熱エネルギーを採取できる地域は 多く，資源量は莫大なものと予想される。

3）これまで数多く見られるように，天然の貯留層を 開発する目的で掘削し, 高温であるが蒸気等の噴出 が見られず, 現在見捨てられている高価な坑井の再 利用ができる。

\section{3. 世界に先がけた米国の現状}

米国では, ロスアラモス国立研究所が，図 2 に示す ニューメキシュ州の北西部のヴァイアスカルデラの近 くのフェントンヒルで, 1971年頃から高温岩体の研究 を始めた。1980年までに, 深さ $3,000 \mathrm{~m}$, 温度 $200^{\circ} \mathrm{C}$ の花崗岩に, 先に述べたような 2 本の坑井と人工貯留 層から成る循環系を造り上げた。これは第 1 期計画と 呼ばれ, 最高286日間にわたる連続熱抽出試験を行い, $3.5 \sim 5.0 \mathrm{MW}$ の熱出力を得ている。この実験によっ

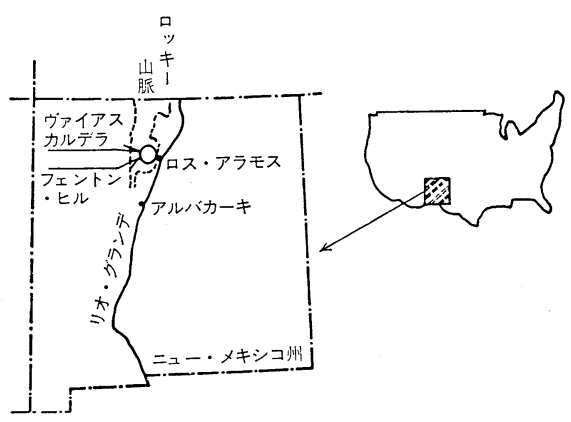

図 2 米国フェントンヒルプロジェクトの 現場試験場の位置

て, ロスアラモス国立研究所は, 高温岩体発電が技術 的に可能であるとの確信を持った。次の段階として, 商業的に高温岩体の開発が可能なことを実証すること を目的に，第 2 期計画として熱出力 $20 \sim 50 \mathrm{MW}$ を目 標に, 深さ $4,000 \mathrm{~m}$, 温度 $300^{\circ} \mathrm{C}$ 以上の岩盤の開発計 画(第 2 期計画)を立案した。この時点で, 米国は日本 と西独にIEAのもとでの研究参加を呼びかけた。日 本は新エネルギー総合開発機構が実施主体となり, 西 独とともにフェントンヒルプロジェクトに参加し, 1980 年度から 7 年間にわたって年間 250 万ドルの資金 を供出するとともに, 延べ27名の研究員を派遣した。 著者も 2 年間以上にわたって同プロジェクトに参加し， 研究活動を行った。1983年には図 3 に示すように $\mathrm{EE}-2$ 井から $21,300 \mathrm{~m}^{3}$ の水を坑井を通して岩盤内に 高圧で注入した。この実験は, 大規模水圧破砕実験 (Exp. 2032) と呼ばれている。AE(Acoustic Emis-

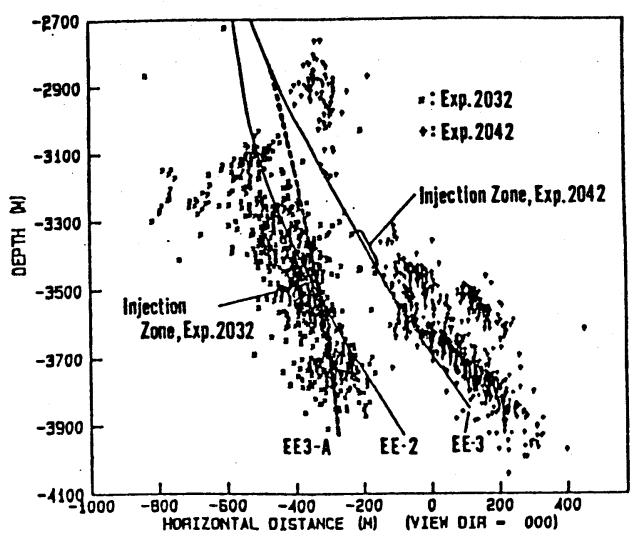

図 3 抗井 EE-2，EE-3 の軌跡と大規模水圧破砕 (Exp. 2032) およびEE-3における水圧破砕実 験(Exp. 2042)によって生じたフラクチャの $A E$ によるマッピング結果 
sion：水圧破砕によって岩盤が破砝する際発生するき わめて微弱な音)によるフラクチャマッピング結果で も表されているように，水圧を加えた裸坑部付近から 大規模な人工貯留層をつくることに成功したが，人工 貯留層となるフラクチャは，目標となる EE-3井には 達しなかった。そこで, この貯留層を貫通するように EE-3井から枝掘り(EE-3A井)を行い, $150 \mathrm{~m} \sim 200 \mathrm{~m}$ の間隔を有する 2 本の坑井 (EE-2 井と EE-3A 井) と これらを導通する人工貯留層から成る循環系をつくり 上げた。

1986年 5 月から 6 月にかけて 1 カ月にわたり, 最大 流量毎分 $1.2 \mathrm{~m}^{3}$ で, 注水井を通してこの人工貯留層 に $25^{\circ} \mathrm{C}$ の水を注入して生産井から熱水を回収する循環 試験を行った。1 月後には注入した水の約70\%を生 産井から回収し, この水の温度は約 $190^{\circ} \mathrm{C}$ に達した。 最終的には約 $10 \mathrm{MW}$ の熱エネルギーの抽出に成功し た。これは初期循環試験と呼ばれ，

1）人工貯留層の大きさのトレーサによる確認,

2）循環ポンプの設計に必要なインピーダンスといわ れる貯留層内を水が流れるときの流動抵抗の把握,

3）回収された循環水に含まれる化学成分などを明ら かにする，

目的で実施された。写真 1 は, 地下 $3,600 \mathrm{~m}$ から熱エ ネルギーを抽出し, 噴出している蒸気の様子を示して いる。ロスアラモス国立研究所の計画によれば, 1988 年 9 月あるいは 10 月から 1 年以上の連続循環試験を実 施し, いろいろな計測を行って, 最終的に技術的およ び経済的に人工貯留層の評価を行ら予定である。

\section{4. 開発が進む日本}

わが国は, 前述のように1986年 9 月末むで 7 年間に わたって, 米国フェントンヒルプロジェクトに参加す るとともに, 国内においても高温岩体発電のための研

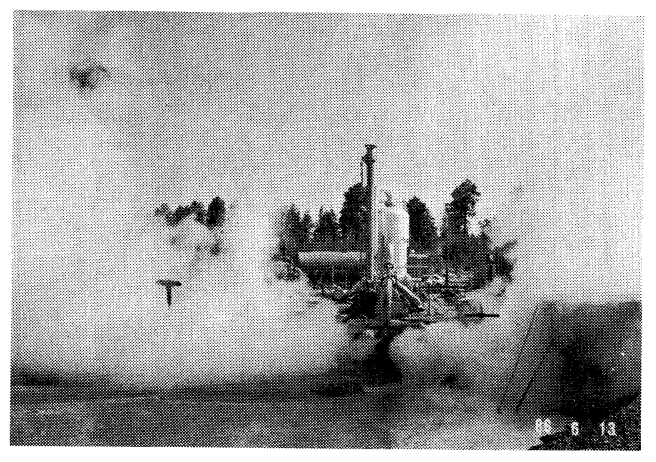

写真 1 米国フェントンヒルプロジェクトの初期循環 試験で地下 3，600m の岩盤により暖められ て噴出する蒸気
究開発が行われている。工業技術院のサンシャイン計 画のもとで，岐阜県焼岳地区において1978年から1983 年までの間, 深さ $300 \mathrm{~m}$ の坑井を数本掘削し， 2 本の 坑井を水圧破砕井, その他の坑井を水圧破砕によって 形成される割れ目の位置を求めるための $\mathrm{AE}$ の観測井 として使用した。1983年には, 水圧破哗井の深さ $200 \mathrm{~m}$ のところで発生させた割れ目を約 $60 \mathrm{~m}$ 成長させ て, 他の坑井と交差させることに成功した。ほぼ1日 にわたって循環試験を実施し, $60^{\circ} \mathrm{C}$ の岩盤に $10^{\circ} \mathrm{C}$ の水 を注入して $30^{\circ} \mathrm{C}$ 以上の温水の回収に成功した。これら 一連の実験の結果焼岳地区では，1）水圧破砕によって， 坑井から割れ目は坑井の軸に沿らよらに発生するが, 成長に伴い岩盤の天然の亀裂などの弱面に沿うょうに 方向を変えたこと，2）観測井に設置した AE の計測装 置によって, 割れ目の位置が検出できること,などの 基礎的知識を得た。

そこでこの地区で得られた研究成果を受け継ぎ, かつ共同研究として参加している米国のフェントンヒ ルプロジェクトの成果を導入して，さらに高温下での 高温岩体開発計画を立てた。このため, いくつかの候 補地を調査した。山形県大蔵村时折地区では, 1980年 から1981年にかけて地熱開発促進調查「銅山川下流」に より数本の地熱調査井を，また石油資源開発(姝)独自 で地熱開発を目標に数本の調査井を掘削した。これら の調査により, 同地区は, 比較的浅部で岩盤が高温に 達し, かつ地熱貯留層の存在が確認されないことがわ かった。その結果, 肘折地区を高温岩体開発の実験場 として選定し，1984年から同地区で現場試験を開始し た。まず, 図 4 亿示すよらに, 既存坑井である SKG-1井とSKG-2井を用いる高温岩体の開発研究計画 を立てた。半径約 $2 \mathrm{~km}$ のカルデラのほぼ中央部に位 置する深さ $1,500 \mathrm{~m}$ の SKG-1 井を $\mathrm{AE}$ の観測井に, SKG-1 井から南方に約 $650 \mathrm{~m}$ 離れた深さ $1,800 \mathrm{~m}$ の SKG-2井を注入井とした。SKG-2の坑井の状態およ び周辺の地質を図 5 亿示す。SKG-2 井周辺の岩盤の 透水率などの調查を実施し， $1,460 \mathrm{~m}$ 以深に存在する 基盤岩である花崗岩内に，人工貯留層を造成すること が適当であると判断した。1985年から予算を新エネル ギー総合開発機構が工業技術院サンシャイン計画推進 本部から受け，研究開発を実施することになった。同 年には，SKG-2 井の坑底部 $14 \mathrm{~m}$ ，パイプを入れな い状態すなわち裸坑として残し，地表から $1,788 \mathrm{~m} の$ 深さまで直径 7 イチの鉄製のパイプを設置した。 1986年 10 月には, 大型ポンプ車 6 台を準備し, SKG-2 井の坑底部に流量毎分 $2 \sim 6 \mathrm{~m}^{3}$, 圧力 $120 \sim 160$ 


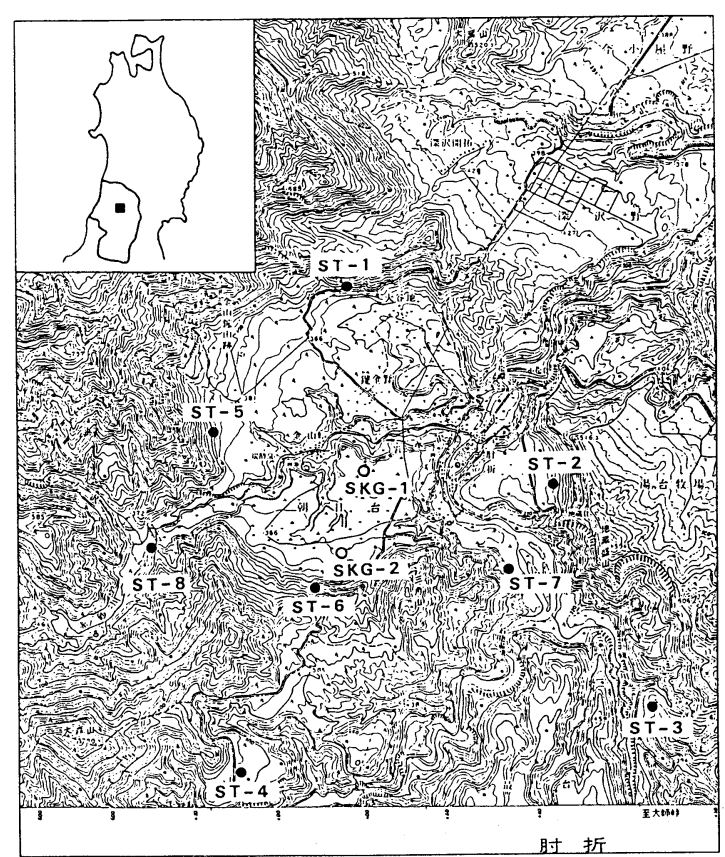

図 4 肘折カルデラと坑井の配置

気圧で注入し，大規模な水圧破砕により岩盤に人工貯 留層となる割れ目を造った。その直後, 坑井の地表部 (坑口といら)の配管に取り付けられているバルブを開 放したところ, 高温の岩盤で暖められた注入水が, 徐 々に温度を上げながら地表に戻り, 約 4 時間後には $100^{\circ} \mathrm{C}$ を越え, 最高温度は $105^{\circ} \mathrm{C}$ 記録した。地下から 噴出した熱水の量は, 約 $380 \mathrm{t}$ 亿達した。この水圧破 砕の際, SKG-1井の深さ $800 \mathrm{~m}$ に 3 軸ジオフォン(指 向性を有する $\mathrm{AE}$ センサーを 3 方向に配置し， 1 台の ソンデで音源を求める装置) と図 4 亿示すように ST-1 ST-8の 8 力所飞微小地震計を配置して, 人 工貯留層の位置の標定(フラクチャマッピングといら)を行った。

1987年には，まずSKG-2井の坑底にジオフォンを， SKG-1井の $800 \mathrm{~m}$ の深さに 3 軸ジオフォンを設置して, 地表観測点である ST-1からST-8の 8 カ所で $5 \mathrm{~kg}$ の ダイナマイトを発破してフラクチャマッピングの結果 を較正した。その結果を図 6 亿示す。フラクチャは主 にSKG-2井から南方に上向きに伸びているものと予 想された。そこで, このフラクチャマッピング結果を 確認する目的で, 割れ目が成長していると思われる位 置すなわちSKG-2井の南方に新たな坑井を掘削する ことにした。HDR-1 井と呼ばれるこの坑井は， SKG-2 井と同じく深さ $1,800 \mathrm{~m}$ まで掘削した。 HDR-1井とSKG-2井との坑井間の距離は $30 \mathrm{~m}$ に設定し

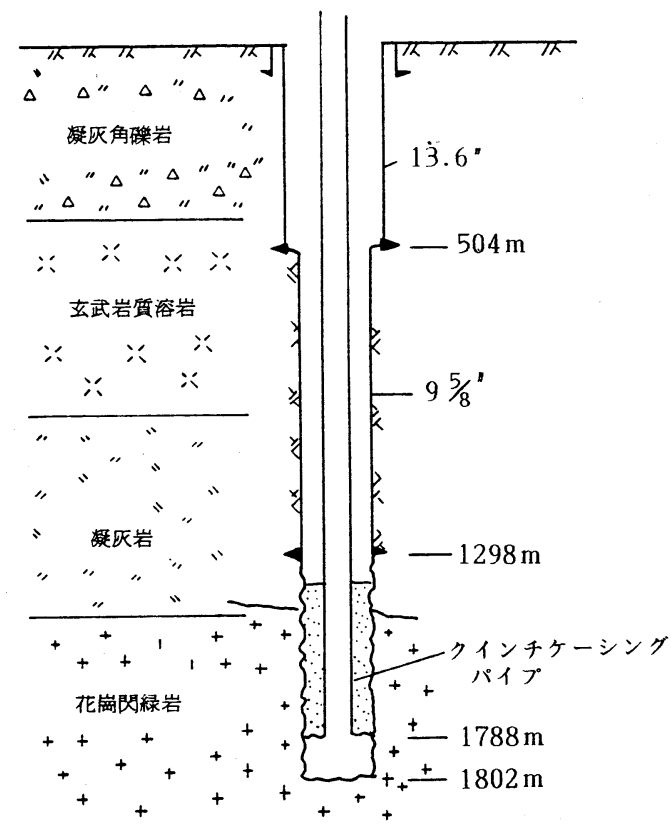

図 5 SKG-2 坑井付近の地質図
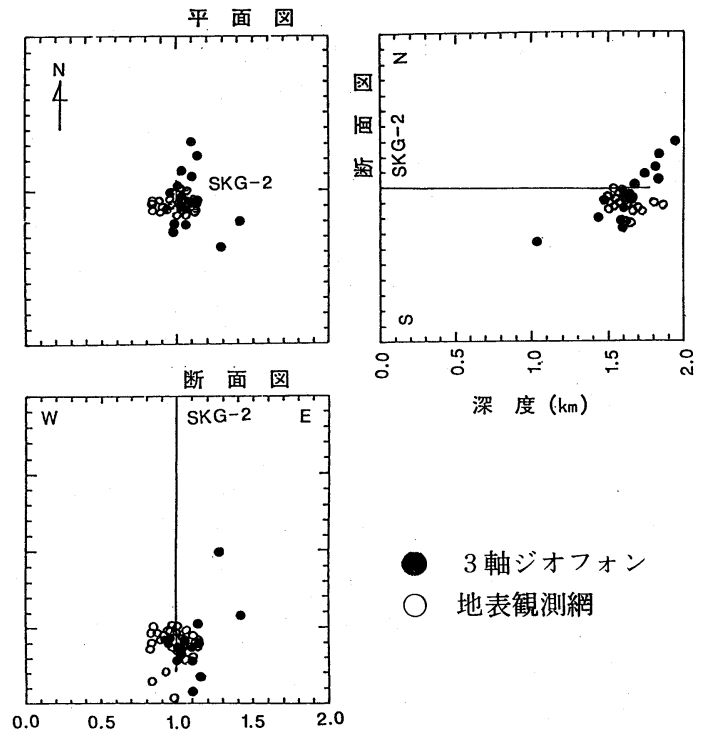

○ 3 軸ジオフォン

地表観測網

図 6 SKG-2における水圧破砕により生じたフラク チャのAEによるマッピング結果

た。写真 2 と示すドリリング・リグで予定どおり掘削 終了後, $\mathrm{SKG}-2$ 井から毎分 $0.6 \sim 1.5 \mathrm{~m}^{3}$ の流量で注 水し, これらの坑井がフラクチャによって導通してい るかどらかの確認試験を実施した。その結果, わず かではあるが，SKG-2 井に注入した水が HDR-1 井 の深さ $1,743 \mathrm{~m}$ と $1,786 \mathrm{~m}$ の 2 力所に流入し, 地表か 


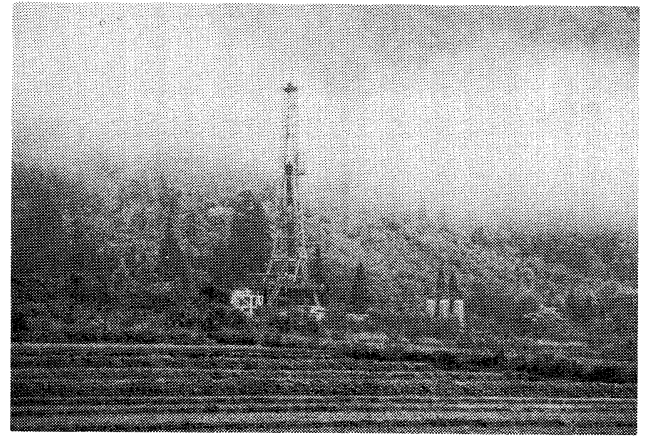

写真 2 时折プロジェクトでHDR-1の掘削に使用 された 3,000m級の掘削リグ

ら回収された。これによって，一応の導通は認められ た。さらに, 水圧破砕井である SKG-2 井の裸坑部か ら，どのように割れ目が発生しているかを，ボアホー ルテレビュアー(超音波により坑井を調べる装置)を用 いて調査した。

その結果, (1)裸坑部の上部から坑井を横切る方向に 2 枚の割れ目と, (2)坑井に沿万方向に他の割れ目が成 長していることが認められた。このらち(1)の割れ目は 岩盤の天然の亀裂に沿って発達したものであり, (2)の 割れ目は坑井の裸坑部に水圧を加えたことにより，引 張応力によって生じた人工の亀裂であると考えられる。 SKG-2 井に水を注入しながら流量検層 (スピナー検 層)を行ったところ，(1)の割れ目に約 $30 \%$ ，(2)の割れ 目に約 $70 \%$ の水が流入していることがわかった。これ らの割れ目がどの方向に成長しているかをいかに確認 するか，またHDR-1井から回収される循環水の流量 を増加するには，どらすればよいのかなどは，今後解 明しなければならない問題である。現時点における計 画では, 时折地区における研究開発は1991年まで続け られ, 熱出力 $10 \sim 20 \mathrm{MW}$ の高温岩体システム開発を 目標に，そのために必要な要素技術の開発を推進する 予定である。

\section{5. 欧州各国でも高温岩体に挑戦}

この高温岩体開発に関する研究は, 日本と米国ばか りでなく，欧州でも積極的に進められている。英国の コーンウォールでは, 図 7 に示すよらに深さ $2,000 \mathrm{~m}$ 級の坑井 RH-11, RH-12 と $2,600 \mathrm{~m}$ 級の坑井 $\mathrm{RH}-15$ を掘り, RH-12 に毎分 $2 \mathrm{~m}^{3}$ 以上の流量で 2 年以上に わたり連続的に注水し，RH-11 と RH-15から回収す る循環試験を行っている。 $90^{\circ} \mathrm{C}$ の岩盤に $20^{\circ} \mathrm{C}$ の水を注 入し, $60^{\circ} \mathrm{C}$ の熱水として回収している。これによって 得られる熱出力は $6 \mathrm{MW}$ である。将来, $6,000 \mathrm{~m}$ の深

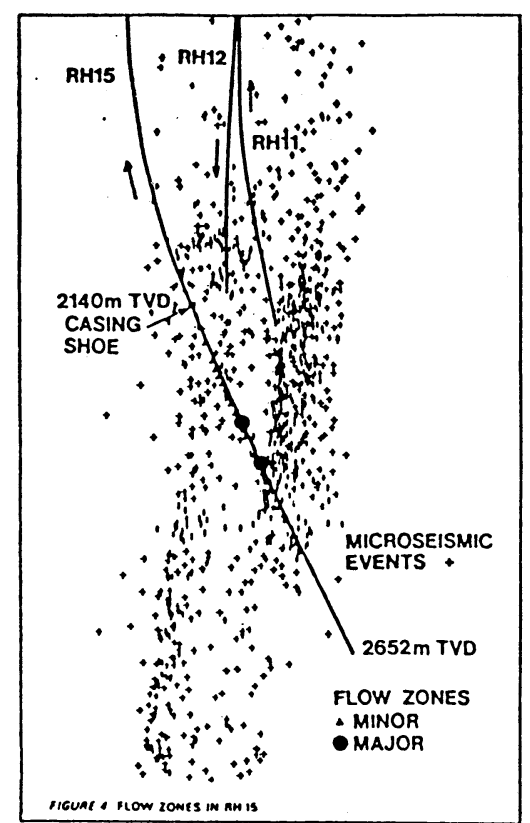

図 7 英国コーンウォールプロジェクトにおける $A E$ クラウドと循環系

さで商業的な高温岩体発電システムを建設しょうとす る計画もあるが，最終的に決定されるまでには，まだ 時間を要するとのことである。

$\mathrm{EC} の も と て ゙$ 西独と仏国が共同で，両国の国境近く で高温岩体の開発を行っている。これは, ソルップロ ジェクトと呼ばれ，1，000万ドルの資金をECが $20 \%$, 西独と仏国がそれぞれ40\%負担している。1987年は, 約 $2,000 \mathrm{~m}$ の坑井を掘削し, 88年にはこの坑井で水圧 破砕を実施して人工貯留層を造成し，89年にもう 1 本 の坑井を人工貯留層を貫くように掘削して, 循環系を 完成する予定である。仏国では，このほか独自でルメ エデモンターニュで高温岩体プロジェクトを推進して いる。このプロジェクトでは，深さ約 $700 \mathrm{~m}$ に人工貯 留層を形成し，循環試験を実施している。また西独で も独自にウラハとファルケンベルグで小規模ながら， 高温岩体開発のための基礎的実験が実施された。

このほか，スウェーデンにおいては，厳しい冬の対 策として，30 $\mathrm{C}$ 程度のお湯が回収できれば，十分経済 的に役立つとの発想から高温岩体の考えを導入して, 深さ500〜 700m の花崗岩に循環系を造成するプロジ ェクトを推進しているところである。

世界の高温岩体開発の現状をまとめ，表 2 に示す。

\section{6. 技術的な開発の課題}

以上，おおよその高温岩体発電方式の概念と開発の 
表 2 各国の高温岩体研究開発プロジェクト一覧

\begin{tabular}{|c|c|c|c|c|c|c|c|c|}
\hline \multirow[b]{2}{*}{ 国 } & \multirow[b]{2}{*}{ 名 } & \multirow[b]{2}{*}{ フィールド位置 } & \multirow[b]{2}{*}{ 岩質 } & \multicolumn{2}{|c|}{ 坑 井 } & \multirow[b]{2}{*}{ 坑底温度 } & \multirow[b]{2}{*}{ 実験期間 } & \multirow[b]{2}{*}{ 循 環 試 験 } \\
\hline & & & & 本数 & $\begin{array}{l}\text { 深 度 } \\
\text { (垂直) }\end{array}$ & & & \\
\hline \multirow[t]{2}{*}{ 米 } & \multirow[t]{2}{*}{ 国 } & $\begin{array}{l}\text { フェントソヒル } \\
(\text { (ューメキシュ }) \\
\text { (第 } 1 \text { 期 })\end{array}$ & 花崗閃緑岩 & 2 & $\begin{array}{l}2,928 \mathrm{~m} \\
3,064 \mathrm{~m}\end{array}$ & $205^{\circ} \mathrm{C}$ & '72 ' 80 年 & $\begin{array}{l}286 \text { 日間の連続抽熱 } \\
\text { 熱出力 } 2 \sim 3 \mathrm{MW}\end{array}$ \\
\hline & & $\begin{array}{l}\text { 同 上 } \\
\text { (第 } 2 \text { 期) }\end{array}$ & 同上 & 2 & $\begin{array}{l}4,400 \mathrm{~m} \\
4,000 \mathrm{~m}\end{array}$ & $327^{\circ} \mathrm{C}$ & '79年 & \begin{tabular}{|c|}
4 週間の抽熱循環 \\
熱出力最大 $10 \mathrm{MW}$ \\
\end{tabular} \\
\hline \multirow[b]{2}{*}{ 英 } & \multirow[b]{2}{*}{ 国 } & コーソウォール & 花崗岩 & 4 & $300 \mathrm{~m}$ & $\begin{array}{l}15^{\circ} \mathrm{C} \\
\text { (推定) }\end{array}$ & '76 '80年 & \\
\hline & & 同上 & 同上 & $\begin{array}{l}2 \\
1\end{array}$ & $\begin{array}{l}2,000 \mathrm{~m} \text { 級 } \\
2,650 \mathrm{~m}\end{array}$ & $\begin{array}{r}80^{\circ} \mathrm{C} \\
105^{\circ} \mathrm{C}\end{array}$ & $\begin{array}{l}\text { '80年〜 } \\
\text { '84年〜 }\end{array}$ & $\begin{array}{l}\text { 長期循環試験実施 } \\
\text { 長期循環試験実施中, } \\
\text { 熱出力 } 6 \mathrm{MW} \\
\end{array}$ \\
\hline \multirow{2}{*}{ 西 } & \multirow{2}{*}{ 独 } & ウラハ & 花崗岩 & 1 & $3,334 \mathrm{~m}$ & $140^{\circ} \mathrm{C}$ & '77～'80年 & $\begin{array}{l}\text { 二重管システムで循環 } \\
\text { テストを終了 }\end{array}$ \\
\hline & & ファルケソベルク & 花崗岩 & 6 & $300 \mathrm{~m}$ 級 & $14^{\circ} \mathrm{C}$ & '79 '81年 & 循環テストを実施 \\
\hline フラ & イ & $\begin{array}{l}\text { ル・メイェ・デ・ } \\
\text { モンターニュ }\end{array}$ & 花崗岩 & 4 & $\begin{array}{l}250 \mathrm{~m} \text { 級 } \\
700 \mathrm{~m} \text { 級 }\end{array}$ & - & $\begin{array}{l}\text { '81 '82年 } \\
\text { '84年 }\end{array}$ & $\begin{array}{l}3 \text { 坑井間で循環テスト } \\
\text { 実施 }\end{array}$ \\
\hline \multirow{4}{*}{ 日 } & \multirow{4}{*}{ 本 } & 焼 岳 & $\begin{array}{l}\text { 砂 岩 } \\
\text { 粘板岩 }\end{array}$ & 7 & $300 \mathrm{~m}$ 級 & $60^{\circ} \mathrm{C}$ & '78 '83年 & 循環系作成 \\
\hline & & 秋の宮 & 凝灰岩 & 1 & $300 \mathrm{~m}$ 級 & $50^{\circ} \mathrm{C}$ & '87年〜 & 水圧破砕 \\
\hline & & 東八幡平 & 凝扊岩 & 2 & $400 \mathrm{~m}$ 級 & $60^{\circ} \mathrm{C}$ & '83年〜 & 循環系作成 \\
\hline & & 肘 折 & 花崗閃緑岩 & 1 & $1,802 \mathrm{~m}$ & $253^{\circ} \mathrm{C}$ & '84年〜 & 一次貯留層造成 \\
\hline スウェ & デン & Fjällbacka & 花崗岩 & 2 & $\begin{array}{c}200 \mathrm{~m} \sim \\
500 \mathrm{~m}\end{array}$ & $17^{\circ} \mathrm{C}$ & '84年〜 & 貯留層造成 \\
\hline
\end{tabular}

現状について述べた。低透水率でかつ高温の岩盤があ るいわゆる高温岩体の適地が選定された後は, 既に大 規模な循環系の造成に成功した米国フェントンヒル， 英国コーンウォールの例を参考にすれば，本システム の開発では以下のよらな手順が一般的であると思われる。

\section{(1) 掘削}

高温岩体発電システムの開発に適当と判断される温 度, 岩質が得られる深度まで, 水圧破砕に使用するた めの坑井を 1 本掘削する。また, この坑井の近傍に観 測井を掘削する。

\section{(2) 水圧破砕}

坑壁面の形状や性状を調べる各種の検層により，高 温の坑底付近で人工破砕可能な部分を選定し，水圧破 研を行う。このときも51本の観測井はその深部に三 軸ジオフォン等の装置を設置し, 水圧破砕によってつ くられた人工的な割れ目 (人工貯留層となる)の位置,
形態を決めるために用いる。

(3) 再掘削

期待する規模の貯留層が造成されたなら，その部分 に向けて観測井深部の掘り増しを行い(この時点で観 測井は生産井あるいは注入井となる)，2坑井を人工的 な割れ目群を介して連結する。

(4) 循環·抽熱

注水井から水を压入し, 生産井から熱水あるいは蒸 気を得て利用する。

これらの各ステージについて以下のような技術開発 課題が挙げられる。
(1) 掘 削

高温岩体を対象とした掘削には，通常の地熱井と同 様，これまでの石油・天然ガス井の開発において用い られてきた掘削技術が適用されている。しかしながら， 開発の対象となる岩盤は石油・天然ガス井の場合では 
比較的低温の堆積層であるのに対し, 高温岩体の場合 には, 約 $300^{\circ} \mathrm{C}$ の硬質の岩盤であり, 掘削能率が著し く低くなる恐れがある。特に, 高温岩体を含めて地熱 井の開発では, 開発費全体に対する掘削費の占める割 合が大きく，適切な掘削技術の開発による掘削費の低 減が経済性の向上に大きく役立つ。

(2) 水圧破碚

水圧破厒に先立って, 掘抜いた地層の岩相・層序, 孔隙率, 浸透性, 亀裂の有無, 岩石の力学的物性等を 把握するため各種の検層が行われる。

水圧破䂶により複数枚のフラクチャから成る貯留層 を造成する場合には, ゾーン・アイソレーション,す なわち坑井内の特定の籄所を区切って加圧する必要が ある。フェントンヒルでは, このために, 坑井内の裸 坑部に耐温性に優れた中空ゴムの内部に水圧を加えて 膨張させる機器すなわちオープンホールパッカーを用 いる方法が採用された。このゴムとしては，EPDM (Ethylene Propylene Diene Multipleterpolymer) が 用いられたが，84時間にわたって初期温度 $200^{\circ} \mathrm{C}$ 以上 の岩盤に対して正常に作動した実績がある。しかし， 坑井の断面形状は必ずしも真円ではなく，また坑壁面 も極めて凹凸のある場合があり，このオープンホール パッカーは現状では必ずしもうまく作動していないの で, ゴムの材質も含め検討·改良の余地がある。

水圧破砕に関しては, パッカーに代表される機器ば かりではなく，水压破碎によって造成されるフラクチ 巾の大きさや方向を支配する地圧や天然の既存の割れ 目の有無等についても検討すべき課題が多い。フェン トンヒルの第 I 期計画において花崗岩体中に造成され た割れ目は，図 8 に示すよらに垂直方向に伸展してい る。この理由として, 水圧破砕の対象となる岩盤の透 水性が小さく天然の割れ目がもともと存在しない健全 な岩盤であれば，水圧破砕によるフラクチャは岩盤内 の最小主応力の方向に対して垂直の方向に伸展すると いらことが挙げられている。これに対して，第期計 画で造成されたフラクチャは，ほ涪同一の岩体内で, 深度が $1,000 \mathrm{~m}$ ほど異なってはいるが，事前の予測 に反して，フラクチャ鉛直方向に進展せず，注入井に 沿って発達したため, 循環システムの完成までに多く の時間を費やした。水圧破砕の結果，どのようなフラ クチャが造成されるかを前もってある程度予測するこ とは非常に重要であるが, そのためには, 岩盤の力学 的諸物性や原位置の岩盤の主応力状態，さらには天然 の割れ目系の有無等を総合的に判断しなければならな い。

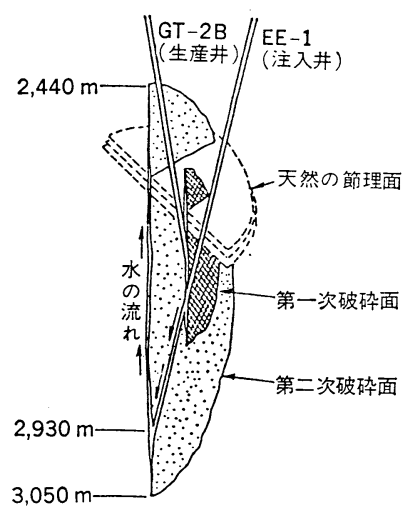

図 8 米国高温岩体第 I 期計画で造成された フラクチャの概念図

さらに，水圧破砕によって造成されるフラクチャの 大きさや方向を探知する技術いわゆるフラクチャマッ ピング技術の開発も大きな課題である。現在このため に，地下深部において前述の 3 軸ジオフォンが使用さ れている。この 3 軸ジオフォンを水圧破砕を行ら坑井 とは別の隣接する坑井深部に配置し, 水圧破砕時ある いはその後に岩盤から発生する微小な音を捉え, ホド グラムの原理あるいは $\mathrm{P}$ 波と $\mathrm{S}$ 波の速度差から微小音 の発生位置を標定する。この 3 軸ジオフォンとは別に, 地表付近の坑井内に多数の地震センサーを配置し, こ れらのセンサーに到達した岩盤の破壊音の到達時間差 から微小地震の発生位置を標定する方法もある。

(3) 再掘削

水圧破砕によって造成されたフラクチャの位置が評 定されれば，その部分を目標として観測井を掘り増し するか，あるいは新規に坑井を掘削して生産井あるい は注入井とし, 地下における循環系を完成させる。こ の際に, 深部岩体内において坑井の方位・傾斜を適切 に制御して目標とする䇢所まで掘削する傾斜掘技術は 必要不可欠のものとなる。

\section{(4) 循環·抽熱}

上述の手順に従って循環系が完成されれば，造成さ れた割れ目群の特性を評価し,さらにこの貯留層が所 定の期間にわたって十分な熱エネルギーを供給する能 力があるかどらかを評価する技術が必要である。この 技術は, 総称して貯留層評価技術と呼ばれているが, この貯留層評価技術は, 実際には(4)の循環系が完成し た後ばかりではなく，(2)の水圧破砕や(3)の再掘削の際 の目標位置の設定の際にも必要となる重要な技術であ る。この(4)の循環·抽熱の段階では, まず短期間の循 環試験を行って, 生産井からの熱水の温度や水質を調 
ベる。さらに,トレーサを用いて人工貯留層の実効体 積を求める方法もある。フェントンヒルにおいては放 射性トレー+ ${ }^{82} \mathrm{Br}$ によって人工貯留層の有効体積を求 めた例もあり，また，熱水中に含まれる化学成分の濃 度から, 地下の人工貯留層の温度を推定する $\mathrm{Na}-\mathrm{K}-\mathrm{Ga}$ 等の地化学温度計法も使用されている。さ らにこの段階においては人工貯留層のインピーダンス を評価することも可能である。このインピーダンスと は, 貯留層からの流体の出口(生産井と人工割れ目系と が交わる箅所) と入口 (注入井と人工割れ目系とが交わ る箅所) の圧力差を出口での流量で除した値で定義さ れ, 人工貯留層内部の水の流れ抵抗を表す指標である。 このインピーダンスが極端に大きければ一定の水を流 すために大きなポンプ動力が必要となり,さらには高 い注水圧を加える結果, 人工貯留層からの逸水率が増 大して経済的な発電システムをつくることは困難とな る。フェントンヒルの第II期計画においてこのイン ピーダンスの目標值として $1 \mathrm{GPa} \cdot \mathrm{s} / \mathrm{m}^{3} か ゙$ 選定された。 その理由はインピーダンスがこの值程度であれば, 生 産井と注入井内部を流れる水の比重差によって，自己 循環効果 (Self-pupming effect) が期待されるためで ある。

\section{7. おわりに}

世界各国において，これまでの高温岩体開発研究の 過程で, さきに述べたようにハードウェアーとソフト ウェアーを含め数多くの新しい技術が開発, 克服され てきた。これらの新技術は, 高温岩体に役立つだけで
なく，たとえば高レベルの核廃棄物の地下貯蔵など広 範囲な分野に貢献している。しかし現在, 高温岩体の 開発に関するすべての技術が開発されたわけではなく， 今後取り組むべき課題も多い。とくに，高温岩体のシ ステムは, 複数の坑井を人工貯留層となる割れ目で導 通させるといら, 特殊な技術が必要なことから, 水圧 破砕で形成される割れ目の位置を, いかに正確に計測 し，かつ水圧破砕を行う以前に予測するかが，重要な ポイントとなる。また, できるだけ岩盤の有する熱エ ネルギーを抽出するためには, 水圧破砕によって多く の割れ目を裸坑部から発生させる技術も，大切である。 また, 調查段階で, どの程度の熱エネルギーの抽出が 可能かを予測するシミュレーション手法の確立も重要 であることは，言らまでもない。莫大な資源量を有し， かつ夢のある高温岩体発電の開発を促進することは, 高温岩体だけでなく他の関連分野にとっても, 今後ま すます重要になるものと考えられる。

\section{文献}

1）高温岩体技術開発一ロスアラモスにおける国際 研究協力プロジェクトの成果,

新エネルギー総合開発機構, 高温岩体検討委員 会作業部会

2) ロスアラモス HDR プロジェクトの水圧破砕, 採鉱と保安(第 1 報〜第 8 報)

3）山口 勉, 地熱技術開発一高温岩体発電を中心 として一, 化学工学, 51, (9)

\section{Hot Dry Rock System}

\section{- New Technology for Geothermal Energy Utilization-}

\section{Michio KURIYAgAWA}

(National Research Institute for Pollution and Resources, MITI)

SYNOPSIS :- Geothermal Energy is one of the most important national energy resources. In Japan, nine geothermal energy power plants are under operation and produce $21.5 \mathrm{MW}$ by developing a natural hydrothermal reservoir located in a depth of $1,000 \mathrm{~m}$ to $2,000 \mathrm{~m}$. In order to increase the electric power from geothermal reservoir, hot dry rock in a high temperature 
without hydrothermal reservoir has been developed in various countries. The concept of the hot dry rock development system was invented by Los Alamos National Laboratory. This paper describes the concept of hot dry rock development and present status of concerned countries which conduct the research and development. Technologies associated in the development are also discussed.

Key Words

Hot dry rock, Geothermal energy, Acoustic emission

\section{液 体微 粒 化 関 係資 料}

记液体の微粒化に関する講演会 講演論文集（各テ共）

第 6 回(昭52）3,000円，第 7 回（昭54），第 8 回（昭55），第 9 回(昭56）各 3,500円， 第10回（昭57） 4,000円，第11回（昭58）3,500円，第12回(昭59）4,000円 第13回（昭60）4,000円，第14回（昭61）4,000円，第15回（昭62）4,000円

（第 1 回〜第 5 回分ご希望の場合は, コピー注文を承ります。）

々液体の微粒化に関する講習会 テキスト（昭51）２,000 円

论第 1 回液体微粒化国際会議（昭53）プロシーディングス 8,000 円（テ共）

$$
\begin{array}{r}
\text { お問い合わせ・申し込み先；(社) 燃 料 協 会 } \\
\text { T101 東京都千代田区外神田6-5-4（偕楽ビル） } \\
\text { TE L }
\end{array}
$$

\begin{tabular}{|c|c|c|c|c|c|}
\hline 论「重質油の利用」 & 1,000円 & 53 年 2 月号 & 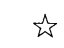 & 「石炭高温ガス化小特集」 & \\
\hline 败「水素エネルギー」 & 1,000 & 53年 5 月号 & & 1,500 & 58年11月号 \\
\hline 论「大気污染防止」 & 1,000 & 53年10月号 & $\hat{\imath}$ & 「石炭関係計測特集」1, 500 & 59年11月号 \\
\hline 抎「石炭化学」 & 1,400 & 54 年 2 月号 & 综 & 「石炭関係機器分析法特集」 & 60 年 11 月号 \\
\hline 约「コークス」 & 1,400 & 54年11月号 & & 「石炭スラリ一燃料特集」 & \\
\hline 「グリーンェネルギー & $-\lrcorner 1,500$ & 55 年 3 月号 & & 2,000 & 61年11月号 \\
\hline 々 「石油製品市場別の & & & 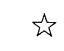 & 「未来都市における & \\
\hline $\begin{aligned} \text { 長期見通し」 } \\
\text { 领創立60周年記念特集 }\end{aligned}$ & 1,500 & 56年11月号 & & $\begin{array}{c}\text { エネルギー技術の展望」特集 } \\
2,500\end{array}$ & 62年11月号 \\
\hline 60周年に際して「燃料 & 忆関する科 & & & & \\
\hline 支術の進歩およ & ゙将来の展皇 & & & & \\
\hline
\end{tabular}

\section{燃料 協会誌特集号}

下記協会誌特集号の在庫が若干ございますので，ご希望の方は，本会宛お申し込み下さい。

$2,000 \quad 57$ 年 10 月号

申し込及先；（社）燃料協 会

厂101 東京都千代田区外神田 $6-5-4$ (偕楽ビル)

T E L $03-834-6456 \sim 8$ 